\title{
Microbial Effects from Biogas Slurry Application on Growing Phase of Turi (Sesbania grandiflora)
}

\author{
Nurzainah Ginting ${ }^{1 *}$, Hasnudi ${ }^{1}$, Yunilas ${ }^{1}$, and M.Adanan Purba ${ }^{2}$ \\ ${ }^{1}$ Animal Production Study Program, Universitas Sumatera Utara, Padang Bulan, Medan 20155, \\ Indonesia \\ ${ }^{2}$ Feed Research Institute Graduate School of Chinese Academy of Agricultural Sciences, Beijing, China \\ *Email: nurzainah@usu.ac.id
}

\begin{abstract}
This research was conducted in Samosir Island, North Sumatera Province, Indonesia which has Inceptisol soil. As this type of soil is generally unfertile, since hundreds years ago, local people added ruminant faeces before planting. This research objective was to prove that application of biogas slurry on growing phase of Turi (Sesbania grandiflora) plant improved microbial population on soil thus plant quality. This research was conducted from May until September 2018. Research design was Completely Randomized Design (CRD) with treatments slurry dosages which were P0: without slurry, P1: 10/ha/year and P2: 20/ha/year. Parameters were chemical composition of slurry, microbial type and population, plant height, total leaf, stem diameter, number of branch and leaf size. The results showed that P0 had no significant effect on every parameters while P1 and P2 improved microbial type and population, plant height, total leaf, stem diameter, number of branch and leaf size $(\mathrm{P}<0.05)$. There was an increasing of microbial population in line with the increasing of slurry dosage. $\mathrm{P} 2$ contained the highest population of bacteria or fungal $(\mathrm{F}<0.05)$ compared to P0 or P1.
\end{abstract}

Keywords: microbial, biogas slurry, dosage, turi (sesbania grandiflora)

Received 08 June 2019 | Revised 17 June 2019| Accepted 1 August 2019

\section{Introduction}

Since hundreds of years ago, the ancestors of the Batak tribe had a proverb, namely Jolo mangorbuk asa manuan. This means that a person has to add fertilizer from livestock before farming. [1] The ancestors of the Batak tribe only kept endemic buffaloes and goats from the beginning even though at this time they also raised pigs. The fertilizer used to grow crops is mainly from buffalo or goats. By a research, it has been proven that the soil type on Samosir Island is Inceptisol, which has relatively low fertility [2]. The soil condition causes the community raise livestock, especially buffaloes to get the benefits of buffalo stool. The 
community caring for buffaloes is related to the peculiarities of buffaloes, which are capable of living in relatively "difficult" areas, especially if the feed is of very low quality. In conditions of feed quality such as this, buffalo growth can be equal or even better than cattle and can still reproduce well [3].

At this time, the Samosir community felt the benefits of buffalo. In general buffalo help the community from its stool as a source of fertilizer, from its strength to help farmers on ploughing and buffalo is a kind of community savings such as in Sri Lanka [4]. With regard to these benefits, more and more buffaloes are kept by the people in Samosir so that there is a shortage of feed. This research used Turi plants which are ideal to be used for livestock feed in Samosir Island because Turi contains high protein and is resistant to dry stress[5].

This research used bio gas slurry as fertilizer. Bio gas as renewable energy is currently being used on Samosir Island. This is related to Samosir Island being determined by the Government of Indonesia as a world tourist destination and according to the provisions of the Sustainable Tourism Observatory (STO) in that location renewable energy must be utilized. Bio gas slurry is a by-product of bio-gas technology. [6] mentioned that people who utilize bio-gas technology will get several benefits at once, namely energy, slurry which is ready to use liquid fertilizer, better environmental aesthetics. More over farmers get various benefits by utilizing bio gas slurry, among others, because the slurry of bio gas is contained with huge population of microbial. In addition [7] stated that environmental health will be better.

[8] stated that in European countries, slurry is not discarded, but is used for soil amendment or improved soil conditions. Slurry derived from livestock feces contains many strains of microorganisms. Strains of microorganisms will naturally adjust to their environment. [9] mentioned there were several microbial strains,i.e Methanobacterium omelianskii, Methanosarcine bacterium, Methanobacterium formicicum, Methanobacterium suboxydans and Methanobacterium sohngenii which could adapt to conditionof anaerobicand mesoppilic. In addition some of slurry microorganisms are able to adapt from anaerobic conditions to aerobic [10].

As ruminant has several kind of stomach and its digestion are support by a huge population of microbial and so does its waste/faeces. Ruminant which eat a lot more fiber would have a lot more microbial in its digestion and its faeces especially cellulolytic bacteria [11]. [12] mentioned that fresh faeces in environment were kept fermenting as its contained with fermented microbial.

This research objective was to prove that application of biogas slurry on growing phase of Turi (Sesbania grandiflora) plant improved microbial population on soil thus plant quality. 


\section{Methods}

The research was conducted from May until September 2018 in Parlondut Village, Pangururan Subdistrict, Samosir Regency, North Sumatra Province. Research design was Completely Randomized Design (CRD) with treatments were P0 : without slurry, P1: slurry dosage of 10 $\mathrm{t} / \mathrm{h} / \mathrm{y}, \mathrm{P} 2$ : slurry dosage $20 \mathrm{t} / \mathrm{h} / \mathrm{y}$. Parameters were microbial population, chemical composition of slurry, plant height, total leaf, stem diameter, and number of branch. The materials used were Sesbania grandiflora plant, slurry of buffalo feces and water hyacinth. There were 4 plants for each treatment and were planted on 1x1 m for every plot.

Data were analyzed, and on significantly different case $(F \geq 0.5)$ or very real $(F \geq 0.1)$ then further tested was conducted by using Duncan test.

1. Plant height

Measurement of plant height using a measuring tape, from the base of the plant above the ground to the end of the plant canopy.

2. Total of leafs

Each of leafs on plants were counted each treatment

3. Stem Diameter

Stem diameter was measured by using calipers. Measurement of stem diameter was done $10 \mathrm{~cm}$ above the ground by clamping the stem of the plant with a caliper.

4. Number of branchs

Number of branchs were counted on every plant

\section{Results and Analysis}

Table 1. Total Microbial, Plant Height, Total Leaf, Stem Diameter,Number of Branch and Leaf size due to application of different dosage of slurry on Sesbania grandiflora plant

\begin{tabular}{lcccc}
\hline \multirow{2}{*}{ Parameters } & \multicolumn{3}{c}{ Treatments } & Average \\
\cline { 2 - 4 } & P0 & P1 & P2 & \\
Total Microbial: & & & & \\
Total Bacterial CFU/ml) & $1.82 \times 10^{7 \mathrm{a}}$ & $3.45 \times 10^{7 \mathrm{a}}$ & $7.55 \times 10^{7 \mathrm{~b}}$ & $4.27 \times 10^{7}$ \\
Total Fungal (CFU/ml) & $1.70 \times 10^{5 \mathrm{a}}$ & $2.80 \times 10^{5 \mathrm{a}}$ & $7.10 \times 10^{5 \mathrm{~b}}$ & $3.86 \times 10^{5}$ \\
Plant Height (cm) & $37.11^{\mathrm{a}}$ & $60.18^{\mathrm{b}}$ & $72.25^{\mathrm{b}}$ & 56.51 \\
Total leaf & $1125^{\mathrm{a}}$ & $1380^{\mathrm{b}}$ & $1530^{\mathrm{b}}$ & 1345 \\
Stem diameter $(\mathrm{cm})$ & $12.5^{\mathrm{a}}$ & $15.7^{\mathrm{b}}$ & $17.2^{\mathrm{b}}$ & 15.13 \\
Number of branch & $27^{\mathrm{a}}$ & $41^{\mathrm{b}}$ & $49^{\mathrm{b}}$ & 39 \\
\hline
\end{tabular}


Table 2. Chemical composition of slurry with buffalo faeces and water hyacinth input

\begin{tabular}{lccc}
\hline No. & Parameter & Unit & Slurry \\
\hline 1 & C-Organik & $\%$ & 3.75 \\
2 & $\mathrm{~N}$ total & $\%$ & 0.24 \\
3 & $\mathrm{C} / \mathrm{N}$ & - & 15.63 \\
4 & $\mathrm{P}_{2} \mathrm{O}_{5}$ & $\%$ & 0.46 \\
5 & $\mathrm{~K}_{2} \mathrm{O}$ & $\%$ & 0.73 \\
6 & $\mathrm{pH}$ & - & 7.1 \\
\hline
\end{tabular}

\subsection{Chemical Composition of Slurry}

$\mathrm{C}$ and $\mathrm{N}$ parameters are needed more to know $\mathrm{C} / \mathrm{N}$ which is a parameter that indicates the level of maturity of a fertilizer. In this study, the $\mathrm{C} / \mathrm{N}$ value of slurry was 15.63 . This figure is in the range of good fertilizer maturity according to SNI standards which states that the level of fertilizer maturity is in the range of 11 to 20 [13]. Low $\mathrm{C} / \mathrm{N}$ indicates that there has been a degradation process in the material so that the nutritional elements can be utilized by plant roots $[14,15]$. According to [6] slurry is a material that has undergone a process of degradation by microbial work in the biodegester. In livestock feces degradation, a process that lasts for 30 days causes degradation that lasts for about 30 days followed by fermentation, causing the maturation of slurry with low C / N. Large population of microbial especially when livestock consume quality feed causes slurry has a low $\mathrm{C} / \mathrm{N}$.

\subsection{Total Microbial}

Microbial population taken from around Turi plant roots showed that P2 treatment showed the highest microbial population as shown in Table 1. Microbial population on P2, which is a slurry application with a dose of $20 \mathrm{t} / \mathrm{h} / \mathrm{t}$, was significantly different from the microbial population with no slurry application. This proves that slurry carries microbial populations in it. [16] and [17] mentioned that ruminantia are cattle whose faeces are found in large microbial populations in accordance with the processes that take place in the digestive process where there is a large microbial population that helps the digestion process of feed ingredients. Specifically for ruminants that a large microbial population not only helps the digestive process but the microbial itself is a significant source of protein to help the life process. About $65 \%$ of protein sources in ruminants come from rumen microbials. Therefore it can be ascertained that ruminantia faeces are used as input for biodigester, so in slurry microbials are found [18]. In addition, microbials found are still active and it has been proven that slurry can be used as a bioactivator, meaning that the microbial population in slurry is quite high. The microbial population that is most commonly found in ruminantia faeces is bacterial and fungal. It was also found in this study that the largest population is bacterial and fungal. By [16] it was added that in soils where ruminantia are grazed, many are bacterial and fungal. 
Ruminantia faeces contain microbial such as Ruminococcus albus, R. Flavefasiens, Bacteroides succinogenes, Butyrivibrio fibrosolvens, Clostridium lockheadi, Eubacterium ruminantium, Bacteroides ruminicol, Streptococcus bovis, Bacteroides amylophylus and Bacteroides ruminicola. In additioned there are fungal such as Neocallimastic frontalis and Sphaeromonas communis which assist the bacterial work in digestion process [10].

Microbial itself has been used by the farmers of Samosir Island since hundreds years ago, who believed that they only could have good harvest if they applied buffalo or goat faeces. Both buffalo or goat are ruminantia. This good believe of Samosir people was proved in this research. Type of soil on Samosir which is Inceptisol which has a low nutrient content have to be treated frequently with fertilizer especially organic fertilizer because it contained with microbial [19]. This type of fertilizer is supported low nutrients soil better because various microbial bacterial soil and fungal are helpful in nutrient preparation on the soil. Microbial, i.e fungal support plant capacity in using nutrients and water through appliction of spores or hyphae which symbiotic with plant roots.

\subsection{Plant height}

As the results of treatment, plant height is sicnificantly higher by P2 and P1 than P0. It means that plant height was improved by adding slurry. [20] mentioned that organic fertilizers contain macro elements $\mathrm{N}, \mathrm{P}, \mathrm{K}$ and these elements support increasing vegetative values such as plant height. In addition physical, chemical and biological properties of the soil could improve by organic fertilizer because of its microbial work. As the result nutrients from unavailable forms into more available forms for plant height growth is available. Organic fertilizer also contribute various other micro nutrients, plant growth hormone and increase water holding.

\subsection{Total leaf}

Leaf is part of plant that mostly consume by animal especially ruminantia. Although the stems are also consumed, in the end the stems are left in the food box. Therefore the rapid and numerous leaf development is a necessity to meet forage consumption.In this study, the total leaf increased markedly in line with the increasing dose of slurry application P2 which was significantly different than P0 ( $\mathrm{F}<0.05)$. The leaves are part of the plant that is highly responsive to fertilizer treatment.

Slurry with its microbial community improve soil respiration. This is in concordance with [21] whom mentioned that soil respiration was related with microbial community and soil respiration was very much improved by P2. 70\% of plant respiration was help through soil respiration. [21] found that soil nutrient was positively related with microbial community as microbial supplied soil with $\mathrm{C}$ and $\mathrm{N}$ thus improved soil quality and plant productivity. Microorganisms produce 
enzymes containing elements of $\mathrm{N}$. The various enzymes produced are useful when slurry is used. This is why slurry is used mostly to remediate the soil or to cultivate plants. $\mathrm{N}$ elements issicnificantly important for crops in the formation of chlorophyll and in the process of photosynthesis. In addition $\mathrm{N}$ accelerate the growth of plants which in this case increase the size of the leaves. Organic fertilizers support the availability of food (nutrients) for plants that can be absorbed from the soil. Organic fertilizers also improve soil physical and chemical properties. Organic fertilizer such as slurry has the ability to support various factors in the soil thus improve grow of plants.

\subsection{Stem Diameter}

Slurry as organic fertilizers contain N, P, K and in this research improve the growth of stem diameter. Application slurry $20 \mathrm{t} / \mathrm{h} / \mathrm{y}$ or $10 \mathrm{t} / \mathrm{h} / \mathrm{y}$ sicnificantly improve stem diameter. The main role of nitrogen for plants is to stimulate overall growth, including stems. In addition, stem diameter is improved due to the availability of element $\mathrm{P}$. This is in accordance with the result of research by [22] which mentioned that $\mathrm{P}$ levels are found in the growth centers of plant.

Plants which has lower P could turns dwarfed. In addition leaves could turn abnormally.

It proved that slurry had a better quality of organic fertilizer and slurry can increase the productivity of the plant. Macro elements in slurry such as N, P, K serve nutrients for soil. Slurry changes the physical properties of the soil, especially the soil structure. Slurry also could keep humidity thus increases the availability of water which is needed on the growing stage of vegetative plants. Macro elements stimulate overall growth, especially the stems, branches and leaves [23].

\subsection{Number of branch}

Due to the application of slurry, the results showed that branching with slurry application was more sicnificantly than application of no slurry. Branching was sicnificantly by adding P2 treatment $20 \mathrm{t} / \mathrm{h} / \mathrm{y}$ than S0. Branching is developed after developing of the leaves and primary branch number suppport plant productivity. The nutrient content of P2 due to application 20 $\mathrm{t} / \mathrm{h} / \mathrm{y}$ of slurry was higher than the control including the macro elements such as N,P, K which highly correlated with the development of leaves and branches. This is in concordance with [23] whom mentioned that macro elements stimulate overall growth, especially the stems, branches and leaves.

\section{Conclusion}

The results showed that biogas slurry contained microbial such as bacterial and fungal and so does plants root and in this case Turi (Sesbania grandiflora). There was a sicnificant increasing of microbial population in line with the increasing of slurry dosage. P2 which was application of 
$20 \mathrm{t}$ slurry/t/y has the highest population of bacterial; i.e $4.27 \times 10^{7} \mathrm{cfu} / \mathrm{ml}$ and highest population of fungal; i.e. $3.86 \times 10^{5} \mathrm{cfu} / \mathrm{ml}$. In addition, P1 and P2 caused significantly (F $<0.05$ ) higher total of plant height, total leaf, stem diameter, number of branch and leaf size.

\section{Acknowledgements}

The author gratefully acknowledgements that financial support from Universitas Sumatera Utara, Medan 20122 Indonesia under TALENTA Research Grant 2018 No. 2590/UN5.1.R/PPM/2017: 16 March 2018.

\section{References}

[1] Local Wisdom of the people of Samosir Regency. Primerly Data

[2]Sudirja, R. 2007. Standar Mutu Pupuk Organik dan Pembenah Tanah. Modul Pelatihan Pembuatan Kompos. Departemen Tenaga Kerja dan Tgransmigrasi RI. Balai Besar Pengembangan dan Perluasan Kerja Lembang.

[3] Dwiyanto and Eko. 2006. Reformasi Birokrasi Pelayanan Publik di Indonesia. Gadjah Mada University Press. Yogyakarta.

[4] Premathilaka S, Seresinhe T, Gajaweera C. 2016. Socio-economic Characteristics of Small Scale Buffalo Farms in Tanamalwila Area in Moneragala District of Srilanka. Proceedings of International Seminar on Livestock Production and Veterinary Tchnology. “ Promoting Livestock and Veterinary Technology for Sustainable Rural Livestock Development". IAARD Press. Indonesian Agency for Agricultural Research and Development. ISBN 978-602-344-147-1

[5] Ginting, N. 2018. Subtitution of pig feed preparation using firewood with biogas in samosir Island: transforming an environmental catastrophe into environmental, social, economic benefits. IOP Conf. Series: Materials Science and Engineering 309 (2018) 012053 doi: $10.1088 / 1757-899 X / 309 / 1 / 012053$

[6] Ginting, N. 2017. Biogas Technology on Supporting "Sustainable" Coffee Farmers in North Sumatera Province, Indonesia. IOP Conf. Series: Materials Science and Engineering 180 (2017) 012112 doi: 10.1088/1757-899X/180/1/012112

[7] Abdeshahian P, Jeng S L, Wai S H, Haslenda H and Chew T L. 2016. Potential of biogas production from farm animal waste in Malaysia. Renewable and Sustainable Energy Reviews 714-23.

[8] Ginting, Nurzainah. 2010. Pemanfaatan Limbah pemotongan Hewan Yang Berkelanjutan. Disertasi S3. Universitas Sumatera Utara. 
[9] Buendia, Immaculada M., Fransisco J. Fernandez, Jose Villasenot and Lourdes Rodriguez. 2009. Feasibility of anaerobic co-digestion as a treatment option of meat industry wastes. Bioresorce Technology 100 (2009) 1903-1909.

[10] Kadarwati, S. 1981. Teori/Reaksi Pembuatan Gas Bio. Proyek Laboratorium PST PPTMGB “LEMIGAS”, Cepu.

[11] Wahyudi and Masduqie. 2004. Penggunaan bungkil inti sawit yang difermentasi dengan cairan rumen kerbau dan saccharomyces cereviceae dalam ransum terhadap ukuran usus ayam broiler. Repository unja.ac.id/1202/1/E10012039-ARTIKEL.

[12] Krause DO, Denman SE, Mackle RI, Morrison M, Rae AL, Attwood GT, McSweeney CS 2003. Opportunities to improve fiber degradation in the rumen microbiology, ecology and genomics. FEMS Microbial Rev 2003 Dec 27 (5) : 663-93. Review. PMID: 14638418.

[13] Standard National of Indonesia. 2011. Department of Agriculture Indonesia.

[14] Badan Penelitian dan Pengkajian Pertanian Sumatera Utara. 2007. Kandungan Unsur Hara Dalam Kompos.

[15] Brito, L.M., J. Coutinho and S.R Smith. 2008. Methods to improve the composting process of the solid fraction of dairy cattle slurry. Bioresource Technology 99 (2008) 8955-8960.

[16] Zhao, Fazhu ; Chengjie Ren; Shelby Shelton; Ziting Wang; Guowei Pang; Ji Chen, Jun Wang. 2017. Grazing intensity influence soil microbial communities and their implications for soil respiration. Agriculture, Ecosystems \& Environment. Volume 249, 1 November 2019, Pages 50-56.

[17] Li, Yuan; Scott X Chang; Lihua Tuan; Qingping Zhang. 2018. Conservation agriculture practices increase soil microbial biomass carbon and nitrogen in arcicultural soils: A global meta-analysis. Soil Biology and Biochemistry. Volume 121, June 2018, Pages 5058.

[18] Jouany, J. P. 1991. Rumen Microbial Metabolism and Ruminant Digestion. Institut National De La Recherce, Paris. 
[19] Simangunsong, S. A. 2006. Pengaruh Pemberian Berbagai MVA dan Pupuk Kandang Ayam pada Tanaman Tembakau Deli Terhadap Serapan P dan Pertumbuhan di Tanah Inceptisol Sampali. Tesis. Universitas Sumatera Utara.

[20] Damanik, M. M. B., B. E. Hasibuan, Fauzi, Sarifuddin, and H. Hanum., 2010. Kesuburan Tanah dan Pemupukan. USU Press. Medan.

[21] Donahue,R.L., Miller, R.W. Shickluna, J.C. (1977). An Introduction to soil and plant growth, ed. New Jersey : Prentice - Hall, Inc.

[22] Rosmarkam, A., dan Yuwono N. W. 2002. Ilmu Kesuburan Tanah. Kanisius. Yokyakarta.

[23] Hardjowigeno. 2007. Biokonveksi : Pemanfaatan Limbah Industri Pertanian. Pusat Antar Universitas Pangan dan Gizi IPB. 